\title{
SERUM TREATMENT OF SCARLATINA.
}

\author{
By MARGARET E. WYLIE.
}

(Ruchill Fever Hospital, Glasgow.)

(With 1 Chart.)

Good results were obtained by Ferry, Pryer and Fisher (1925) in the treatment of cases of scarlatina with concentrated antitoxin, obtained from horses treated with toxin of scarlatina derived from streptococci. This antitoxin was supplied commercially by Parke, Davis and Co. It has been used in the present investigation.

General nature and treatment of the patients in the present series.

The 116 cases of scarlet fever considered in this report were treated in the Ruchill Fever Hospital, Glasgow, between February 1926 and July 1927. The chance inclusion of any atypical case of diphtheria was precluded by the examination of a throat swab, taken from each patient on admission. Only acutely ill patients were selected. The selection was based on the height of the temperature, the rapidity of the pulse, the condition of the throat, the brilliancy of the rash and the degree of prostration.

The patients came from all types of homes and represented all grades in the social scale. The medical treatment after admission was essentially the same in all cases. Uncomplicated cases were allowed up on the 28 th day and dismissed on the 42nd day from the onset of the illness. Complications of the same type were treated similarly. The only variable factor in the treatment was the administration or non-administration of antitoxin or convalescent serum. Twenty-nine patients received no serum of any kind. Eighty-four patients were treated with the concentrated antitoxin above mentioned. Of these 84 cases, 70 received 10 c.c. of antitoxin and 14 received 20-30 c.c. of antitoxin. Convalescent serum in doses of 6.5-8 c.c. was given in three cases. This serum was made by incubating the serum of scarlet fever patients (obtained by vein puncture on the $3 \mathrm{rd}-4$ th week of illness) at a temperature of $37^{\circ} \mathrm{C}$. for 45 minutes on three successive days. All injections were given intramuscularly.

\section{Classification adopted.}

For purposes of comparison the cases were divided into the six groups shown in Table $I$ according to the type of case and the treatment given. It should be noted that the cases of Group I were less severe than the cases of Group II as the regulations of the hospital required the administration of serum to acutely ill patients. 
Table I. Showing the classification and treatment of cases of scarlet fever, and the occurrence of complications.

\begin{tabular}{clclc} 
Group & \multicolumn{1}{c}{ Disease } & $\begin{array}{c}\text { No. of } \\
\text { cases }\end{array}$ & \multicolumn{1}{c}{$\begin{array}{c}\text { Thich } \\
\text { Treatment }\end{array}$} & $\begin{array}{c}\text { developed } \\
\text { complications }\end{array}$ \\
I & Scarlet fever & 29 & No antitoxin & 17 \\
II & " & 68 & 10 c.c. antitoxin & 36 \\
III & Toxic scarlet fever & 10 & $20-30$ c.c. antitoxin & 6 \\
IV & 4 & 20 c.c. antitoxin & 3 \\
V & Septic scarlet fever & 2 & 10 c.c. antitoxin & 1 \\
VI & Scarlet fever & 3 & $6 \cdot 5-8$ c.c. convalescent serum & 2
\end{tabular}

\section{Clinical features of the several groups.}

In Groups I and II, ages 1-44 years, most of the patients were well nourished and had slight generalised rashes. The patients in Groups I and II are strictly comparable as regards previous infection, symptoms, glandular involvement and presence of rhinitis, in the condition of throat, tongue, heart and lungs and the presence of minor abnormalities. A comparison of temperature, pulse, rash and the estimation of the severity of the illness from clinical findings shows

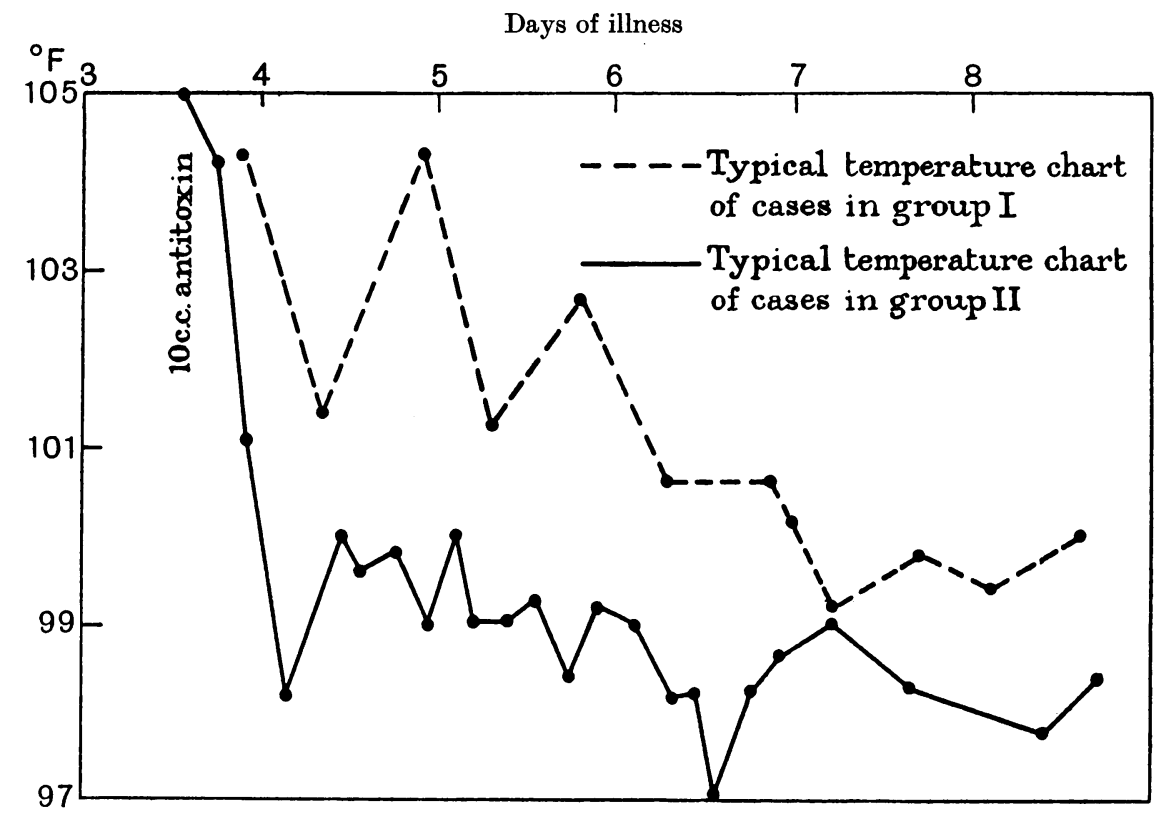

Chart 1. Showing typical temperature charts of cases in group 1 (no antitoxin) and in group 2 (10 c.c. antitoxin).

that, although these two groups represent patients infected with the same type of scarlet fever, the cases in Group II were more severe than those of Group I. Therefore, in treating the cases of Group II with 10 c.c. of scarlet fever streptococcus antitoxin, the efficacy of the serum is being put to a greater test than if applied to cases in Group I. Chart I shows typical temperature charts of cases in Groups I and II. 
In Group III, ages 16-44 years, most of the patients were well nourished, all the patients were very acutely ill and two showed signs of toxaemia. All had well-marked generalised rashes.

All four patients in Group IV, whilst well nourished, suffered from toxic scarlet fever and were very acutely ill. The ages of the cases were 2, 3, 4 and 7 years. Two cases had no rash while in hospital, and two had a faint rash with petechial haemorrhages on the trunk and extremities. All four patients were delirious during the acute phase of the illness. Three of these died within 11 days after admission to hospital.

In Group V, ages 3 and 6 years, both cases suffered from septic scarlet fever; they were well nourished. One appeared very acutely ill on admission, and one mildly ill. One patient died 6 days after admission.

The clinical features of the case in Group VI were similar to those in Groups I and II, the sole difference was that Group VI received $6 \cdot 5-8$ c.c. of convalescent serum.

\section{RESUlts OF SERUM TREATMENT.}

\section{General clinical improvement.}

The most striking result of the administration of the antitoxin in the first few days of illness was the rapid clinical improvement as shown by the disappearance of the toxaemic symptoms. A patient who before the injection was delirious, restless and sleepless, felt well after a few hours. Vomiting ceased, the throat became less painful, the cervical glands diminished in size, cyanosis disappeared, the rash faded and moderate desquamation was followed by fine unobtrusive powdering. With the fading of the rash, usually in $6-12$ hours after the administration of serum, there followed a critical fall of temperature, from hyperpyrexia to a sub-febrile level, accompanied by a general improvement in the pulse. Indeed the patient emerged from the acute stage of the disease to the security of convalescence.

\section{Effect on temperature and pulse.}

Graph 1 shows the rapid critical fall in temperature. In the subsequent tables showing the fall in temperature and pulse the temperature is considered raised until it remains at $97^{\circ} \mathrm{F}$. and the pulse is considered accelerated until it remains at approximately 80 beats per minute. Birkhaug (1925) and Park (1925) described similar results with Dochez's serum. On the other hand in Graham's (1925) experience the serum gave little apparent relief. It is of considerable interest that the results obtained in the present investigation correspond closely with those obtained by Benson and Maciver (1926). Gordon (1927) found the total febrile period in days shorter in patients receiving serum. Lindsay, Rice and Selinger (1927) state that the febrile period was 7-8 days in treated and 9 days in untreated cases. Not only do the results shown below (Table II) bear out those of Lindsay, Rice and Selinger (1927), but they also show that, provided the antitoxin is given during the first six 
days of illness, the same speedy return to normal is obtained irrespective of the actual date of administration.

Table II. Showing the days on which the temperature and pulse became normal in the three groups of scarlet fever patients.

$\begin{array}{clcc}\text { Group } & \text { Treatment } & \begin{array}{c}\text { Temp. normal } \\ \text { (average) }\end{array} & \begin{array}{c}\text { Pulse normal } \\ \text { (average) }\end{array} \\ \text { I } & \text { No antitoxin } & \text { 5th day } & \text { 8th day } \\ \text { II } & \text { Antitoxin } & \text { 2nd ”, } & \text { 3rd ”, } \\ \text { III } & \text { Antitoxin } & \text { 3rd ", } & \text { 3rd ”, }\end{array}$

While the return of temperature and pulse to the normal occurred earlier in the cases in the present series than in the series of Lindsay, Rice and Selinger (1927) yet in both series the return occurred earlier in the cases treated with antitoxin than in untreated cases.

Gordon (1927) reports that the immediate result of injection of serum has frequently been a rise rather than a fall in temperature, possibly the result of foreign protein injected. In 53 per cent. of my cases a rise in temperature occurred immediately after the administration of antitoxin, the rise being most marked in mild, and least in severe cases. The rise in temperature occurred more frequently after the giving of 20-30 c.c. antitoxin than after 10 c.c., although the actual rise in temperature was smaller.

\section{INFLUENCE OF SERUM ON THE DEVELOPMENT OF COMPLICATIONS.}

Kinloch (1925) states that serum treatment of scarlet fever reduces serious complications, while Lindsay, Rice and Selinger (1927) emphasise the importance of the early use of sufficient antitoxin. Park (1925) concludes that while antitoxin has little effect on complications, if they have already occurred, it is of service in preventing them. Dick and Dick (1925) hold that the early giving of antitoxin shortens the disease and diminishes complications. The results in the present series of cases demonstrate that the serum employed exerted the same effects (Table III).

Table III. Showing the development of complications in the first two groups of scarlet fever cases.

\begin{tabular}{ccccccc} 
Group & Treatment & $\begin{array}{c}\text { No. of cases } \\
\text { which developed } \\
\text { complications }\end{array}$ & \multicolumn{1}{c}{$\begin{array}{c}\text { No. of cases which developed one or } \\
\text { more complications }\end{array}$} \\
I & No antitoxin & $17 / 29$ & $59 \%$ & $28 \%$ & $10 \%$ & $7 \%$ \\
II & 10 c.c. antitoxin & $36 / 68$ & 53 & 21 & 6 & $-7 \%$
\end{tabular}

Although the number of cases in this series is too small to permit of detailed conclusions they definitely demonstrate that the incidence of complications was greater in mild cases which were not treated with antitoxin than in more severe cases treated with 10 c.c. antitoxin.

Blake, Trask and Lynch (1924) consider that septic processes may continue to advance although the patient has produced sufficient antitoxin to cure the 
specific toxaemia. They have found it impossible to demonstrate that the scarlet fever antiserum possesses any therapeutic value in post-scarlatinal sepsis after the rash has faded. O'Brien (1927) at first believed that no antitoxin or other serum available had any direct action on septic complications. He qualified this opinion with the remark that many further observations were required before a definite conclusion could be reached. Birkhaug (1925) found the incidence of septic complications low in cases treated with Dochez's serum prior to the fourth day of disease. In my series 23 per cent. of the cases in Group I and 40 per cent. of the cases in Group II developed septic complications. These results are in direct disagreement with Birkhaug's conclusion.

Benson and Maciver (1926) found that the administration of serum even on the first day of illness apparently does not act as an absolute safeguard against the subsequent development of septic complications during convalescence. This observation is confirmed in the present series, i.e. the cases in Group II developed complications from the 5th to the 81st day after the onset of illness. Gordon (1927) states that the favourable effect of scarlet fever antitoxin is evinced by a lessened severity and duration of all complications. The following findings do not support Gordon's statement. The septic complications in the cases of Group I lasted from 3-15 (av. 9) days; in Group II they lasted from 5-30 (av. 15) days. The non-septic complications in Group I lasted 4-25 (av. 8) days while in Group II they lasted 6-37 (av. 21) days. From detailed analysis of the present series, more exact findings are obtainable. Thus Tables Nos. IV and V demonstrate the important fact that while powerless to delay the onset of non-septic complications, serum has the effect of diminishing the frequency of their occurrence.

Table IV. Showing the onset of non-septic complications in Groups I, II and III.

$\begin{array}{lccccc} & & \begin{array}{c}\text { Group I } \\ \text { Day of illness }\end{array} & \begin{array}{c}\text { Group II } \\ \text { Day of illness }\end{array} & \begin{array}{c}\text { Group III } \\ \text { Day of illness }\end{array} \\ \text { Adenitis } & \ldots & \ldots & 17 & 10 & 14 \\ \text { Arthritis } \ldots & \ldots & 10 & 11 & - \\ \text { Endocarditis } & \ldots & 27 & 19 & - \\ \text { Nephritis } & \ldots & \ldots & 20 & 10 & 44 \\ \text { Serous rhinitis } & \ldots & 15 & 16 & 5 \\ \text { Broncho-pneumonia } & 6 & - & - \\ \text { Lobar pneumonia } & \ldots & -\ldots & - & - \\ \text { Rheumatic torticolles } & 8 & - & 13\end{array}$

DURATION OF RESIDENCE IN HOSPITAL.

The cases of scarlet fever in Group I, which were not treated with antitoxin, had an average residence of 56 days. The more severe cases (Group II) treated with 10 c.c. antitoxin resided on an average 53 days, while the cases in Group III, still more grave and treated with 20-30 c.c. antitoxin, resided 58 days. No attempt was made to dismiss cases at the earliest opportunity, as it was considered desirable to keep the cases under close observation throughout the entire illness and period of convalescence. 
Table V. Showing the incidence of non-septic complications in Groups I, II and III.

\begin{tabular}{lllccc} 
& & \multicolumn{3}{c}{ Percentages of cases in } \\
\cline { 3 - 6 } & & Group I & Group II & Group III \\
Adenitis & $\ldots$ & $\ldots$ & 17 & 15 & 33 \\
Arthritis & $\ldots$ & $\ldots$ & 13 & 8 & - \\
Endocarditis & $\ldots$ & 10 & 3 & -11 \\
Nephritis & $\ldots$ & $\ldots$ & 17 & 6 & 11 \\
Serous rhinitis & $\ldots$ & 10 & 3 & 11 \\
Broncho-pneumonia & 3 & - & - \\
Lobar pneumonia & $\ldots$ &.- & 3 & - & 66
\end{tabular}

\section{Conclusions.}

1. Scarlet fever streptococcus antitoxin is of definite therapeutic value in scarlet fever.

2. There is evidence that scarlet fever streptococcus antitoxin has some definite effect in reducing the occurrence of non-septic complications.

3. There is no evidence that scarlet fever streptococcus antitoxin (a) diminishes the occurrence of septic complications, (b) delays the onset either of septic or of non-septic complications, or $(c)$ shortens the duration of septic or non-septic complications.

I wish to acknowledge my indebtedness to Dr Elliott, Medical Superintendent of the Ruchill Fever Hospital, for permission to carry out this investigation.

\section{REFERENCES.}

Benson, W. T. and Maciver, D. F. (1926). Edin. Med. J. 33, 701.

BirkhaUg, K. E. (1925). Bull. Johns Hopkins Hosp. 36, 134.

Blake, F. G., Trask, J. D. and Lynch, J. R. (1924). J. Amer. Med. Assoc. 82, 713.

Dick, G. F. and Dick, G. H. (1925). Ibid. 84, 803.

Ferry, N. S., Pryer, R. W. and Fisher, L. W. (1925). J. of Lab. and Clin. Med. 10, 753. Gondon, J. E. (1927). J. Amer. Med. Assoc. 88, 382.

Graham, R. H. (1925). Ibid. 85, 95.

Kinloch, J. P. (1925). M.O.H. Rep. for City of Aberdeen, p. 5.

Lindsay, J. W., Rice, E. C. and Selinger, M. A. (1927). J. Amer. Med. Assoc. 86, 1191.

O'Brien, R. A. (1927). Proc. Roy. Soc: Med. 20, 151.

PARK, W. H. (1925). J. Amer. Med. Assoc., 85, 1180.

(MS. received for publication 25. Iv. 1930.-Ed.) 